\title{
Firm Size, Asset Tangibility, Growth, Volatility, Dividends and the Capital Structure of Nigerian Quoted Firms
}

\author{
Oluseun Paseda \\ Department of Finance, Faculty of Economics and Management Sciences, University of Ibadan, Ibadan, Nigeria \\ Email address: \\ seunpash@yahoo.com \\ To cite this article: \\ Oluseun Paseda. Firm Size, Asset Tangibility, Growth, Volatility, Dividends and the Capital Structure of Nigerian Quoted Firms. Journal of \\ Finance and Accounting. Vol. 9, No. 2, 2021, pp. 36-52. doi: 10.11648/j.jfa.20210902.13
}

Received: March 11, 2021; Accepted: March 23, 2021; Published: April 29, 2021

\begin{abstract}
Empirical work on capital structure in emerging markets like Nigeria has been sparse and met with low explanatory power. This study investigates the determinants of capital structure in Nigeria. The population of study comprises all non-financial corporations quoted on the Nigerian Stock Exchange (NSE) for the period 1999-2014 out of which 50 companies that met the minimum data criteria were utilized. Using panel data least squares regression, modified to weighted (cross section- and period-) models, the research documents the following findings. First, the factors that exert positive influence on corporate borrowing include firm age, intangible assets and expected inflation while those factors that exert negative influence on capital structure include tangible assets, growth, size, volatility of earnings, profitability, liquidity, dividend-paying status and uniqueness of industry. The results were, at best, mixed with respect to the portability of pecking order, target adjustment, trade-off, agency and market conditions models. The pecking order beats the trade-off model based on the signs of coefficients of firm-level attributes. In order words, asymmetric information explains why smaller, less profitable, less liquid firms with more risky intangible assets and which are low dividend-payers end up relying primarily on debt financing and vice versa. The study recommends the use of leases for financially- and collateral-constrained firms as well as instruments that facilitate information symmetry in financial markets.
\end{abstract}

Keywords: Capital Structure, Firm-Specific Characteristics, Pecking Order, Trade-off

\section{Introduction}

Capital structure remains an active area of financial research. Despite decades of research, there is much contention about the cross-sectional determinants of corporate capital structure. Although there are strong patterns in the data [42], the explanatory power of the variables in the cross-section remains disappointing [39, 43, 47, 60]. One conclusion that can be drawn from this state of empirical capital structure research is that further research is required on the theoretical determinants of capital structure.

Myers [71] in 1984 asked "How do firms choose their capital structures?" in his presidential address to the American Finance Association, and quickly answered "We don't know." Twenty four years later, Lemmon, Roberts \& Zender [60] began with the similar question “....after decades of research, how much do we really know (about corporate capital structures)?" and found that "The adjusted R-squares from traditional leverage regressions using previously identified determinants range from $18 \%$ to $29 \%$, depending on the specification. In contrast, the adjusted R-square from a regression of leverage on firm fixed effects (statistical proxies for the permanent component of leverage) is $60 \%$, implying that a substantial variation in leverage in a panel of firms is time-invariant and is largely unexplained by previously identified determinants." DeAngelo \& Roll [31] find that leverage is actually far from time-invariant and that "leverage cross-sections more than a few years apart differ markedly." This poses an even greater challenge to existing theories [94] and exacerbates the unsettled debate on capital structure policy. As Bolton [19] distressingly puts it, "not only is most of the variation in the cross-section unexplained but also what is driving the time-series variation is poorly understood."

Much of the research since the seminal work of Modigliani \& Miller [68] has focused on testing the implications of two views of capital structure namely: static trade-off model in which firms form a leverage target that optimally balances 
various costs (e.g., costs of financial distress, bondholderstockholder agency conflicts/costs) and benefits (e.g., tax savings, mitigated manager-stockholder conflicts) of debt, and the pecking order model of Myers and Majluf [73] and Myers [71] in which firms follow a financing hierarchy designed to minimize adverse selection costs of security issuance. Other common views include market timing and agency models. Agency models have several versions but their most vocal exposition is embodied in Jensen's [55] free cash flow theory. Empirically, these models have experienced both successes and challenges [16, 35-36, 41, 53, 58, 61, 8990]. Each view succeeds in explaining a number of broad patterns in observed capital structures, such as association between leverage and various firm characteristics [42] or manager characteristics [29] and the aggregate use of different sources of capital.

However, no view has succeeded in explaining much of the observed heterogeneity in capital structures, leverage changes, or security issuance decisions [47-48, 89]. Specifically, the explanatory power of the variables in the cross-section remains disappointing.

The presence of market imperfections in both developed and developing countries suggests that emerging markets also provide an excellent laboratory for capital structure tests that incorporate the impact of market frictions. This study seeks to add an African flavor to the capital structure debate and thus fill an important gap in the corporate finance literature. Some attempts to bridge this emerging market line of research, and specifically, studies on Arab countries [15], and African economies, include [87-88, 9, 78, 86, 2, 50, 5, 1, $3,34] ;[12,74]$, and [4]. The inclusion of African firms for such a study provides an opportunity for comparisons among African countries as well as between African and Industrialized countries, which have been heavily researched. To the extent that emerging markets in Africa are similar to the industrialized or non African emerging markets, they provide us with independent samples to test the extant capital structure theories. In addition, to the extent that they have different institutional structures this will increase economists' ability to distinguish among alternative theories and thus enable the profession to come up with theories that apply to Africa. This research adds to the existing African studies on capital structure.

Further, as Myers [72] puts it, there is no universal theory of capital structure and there is no reason to expect one. Several extant capital structure models, such as the tradeoff, pecking order, target-adjustment, market timing and agency models, have been tested using data from developed markets. The portability of those models in emerging markets is a matter of empirical tests so that if those theories do not hold, their implications too may be irrelevant to economists and corporate finance types in emerging market domain.

The purpose of this study is to evaluate the impact of firmsize, asset tangibility, age, growth, volatility, profitability and dividend policy on the borrowing behavior of Nigerian quoted firms. Chandrasekharan [23] examines the determinants of capital structure of Nigerian listed firms for a sample of 87 firms over a five-year period utilizing five firmspecific factors namely size, age, growth, profitability, and asset tangibility. This five firm-specific factor approach to capital structure investigation is considered too narrow and limiting in insights despite the study's R-square of 54 percent. Similar insight-limiting challenges are notable with empirical papers such as [10] which capture only the Food and Beverages sector. This study attempts to capture a wider set of firm-specific characteristics than many prior works on Nigerian quoted firms. [74] investigates the interaction between capital structure and measures of corporate performance such as return on assets (ROA), return on capital employed (ROCE), and so on. Despite the huge analysis and robust results in [74], the investigation of capital structure determinants was not a primary concern for the study.

This paper is similar to [81-82], and [83] that consider tax effects on capital structure, tax benefit curves and debt conservatism respectively. This paper's key results are: First, the factors that exert positive influences on borrowing include prior borrowing or prior leverage, non-debt tax shields, assets' riskiness represented by $\mathrm{R} \& \mathrm{D}$ and other intangible assets, firm age and debt market access represented by rating. Second, the factors that exert negative influences on borrowing are marginal tax rate, tangibility of assets in place (proxy for collateral value), growth opportunities, size of the firm, volatility of operating earnings, profitability, liquidity and dividend-paying status.

The rest of this paper is organized as follows: Section 1 reviews prior work and theoretical framework on capital structure. Section 2 considers the methodology including data description, sample construction and definition of variables. Section 3 discusses the empirical results of the impact of firm characteristics on capital structure. Section 4 presents robustness checks and implications of results and the fifth section concludes the paper.

\section{Literature Review and Theoretical Framework}

The modern theory of capital structure began with the celebrated papers of Modigliani \& Miller (MM [68, 69]). They developed a framework for addressing the question of how a firm's financial choices, such as its use of debt rather than equity financing, affect its cost of capital and consequently its investment behaviour. The MM [68] paper's central result is that, in a setting with complete and perfect capital markets, a firm's total market value is invariant to its borrowing behaviour. This powerful result demonstrated by their arbitrage proof sparked a major revolution in finance. In other words, MM pointed the direction that corporate finance theories must follow by showing under what conditions capital structure is irrelevant. Since then, many researchers have followed the path they mapped. The following six decades witnessed the thorough development of the perfect market theory in finance applications and its spread 
throughout economics. The diminishing returns associated with the maturing of this research have led finance scholars to concentrate increasingly on relaxing various perfect market assumptions, with growing attention to taxes, bankruptcy effects, agency costs and information effects.

Miller [66] observes that the tax advantage of corporate borrowing outweighs the expected costs of financial distress so much so that firms appeared to be "under-levered" relative to their perceived debt capacity. He rationalized that the personal tax disadvantage of debt is a significant countervailing force to the corporate tax advantage to debt usage. In fact, he provided an equilibrium situation where the personal tax disadvantage of debt completely offsets the corporate tax shield benefit of debt so that capital structure becomes irrelevant at the corporate level. Miller's gain from leverage formula is a cornerstone of the trade-off model of capital structure which has many authors.

DeAngelo \& Masulis [30] extend Miller's work by analyzing the effect of tax shields other than interest payments on debt, e.g, non-cash charges such as accounting depreciation, oil depletion allowances, and investment tax credits. They are able to demonstrate the existence of an optimal (nonzero) corporate use of debt while still maintaining the assumption of zero bankruptcy (and zero agency) costs.

DeAngelo \& Masulis [30] demonstrate that each firm has a unique interior optimum capital structure in market equilibrium in a world characterized by (i) the equity-biased personal tax code and (ii) corporate tax shield substitutes for debt and/or positive default costs. From their expanded model, they derive the following testable hypotheses:

$\mathrm{H}_{1}$ : The leverage decision is relevant to the individual firm in the sense that a pure change in debt (holding investment constant) will have a valuation impact.

$\mathrm{H}_{2}$ : In equilibrium, relative market prices will imply a net (corporate and personal) tax advantage to corporate debt financing.

$\mathrm{H}_{3}$ : Ceteris paribus, decreases in allowable investment related tax shields (e.g., depreciation deductions or investment tax credits) due to changes in the corporate tax code or due to changes in inflation which reduce the real value of tax shields will increase the amount of debt that firms employ. In cross-sectional analysis, firms with lower investment related tax shields (holding before-tax earnings constant) will employ greater debt in their capital structures.

$\mathrm{H}_{4}$ : Ceteris paribus, decreases in firms' marginal bankruptcy costs will increase the use of leverage. Crosssectionally, firms subject to greater marginal bankruptcy costs will employ less debt.

$\mathrm{H}_{5}$ : Ceteris paribus, as the corporate tax rate is raised, firms will substitute debt for equity financing. Crosssectionally, firms subject to lower corporate tax rates will employ less debt in their capital structures (holding earnings constant).

The novel idea that investment tax credits and depreciation expenses do serve as tax shield substitutes for interest expenses has a deal of theoretical appeal. The DeAngelo \&
Masulis model predicts that firms will select a debt level that is inversely related to the level of available tax shield substitutes. Graham and Tucker [46], utilizing a sample of 44 tax shelter cases to investigate tax shelter activity, present strong evidence in support of this argument. They find that firms use less debt when they engage in alternative tax sheltering.

In summary, in the DeAngelo-Masulis (1980) model, the tax shield benefit of debt kicks in only after other sources of tax shield benefits are exhausted, i.e., depreciation, losses and investment tax credit. These non-debt tax shields (NDTS) serve as substitutes to debt as in the hypothesis $\mathrm{H}_{3}$ above. This substitution hypothesis presents a theoretical framework in which leverage is a decreasing function of non-debt tax shields. In other words, the tax shield benefit of debt is moderated by the presence of non-debt tax shield benefits. A positive relationship between debt ratios and non-debt tax shields (NDTS) has been interpreted as an instrumental variable for the debt collateral i.e. higher NDTS signal higher collateral value of assets (Copeland, Weston \&Shastri, 2005).

Agency-theoretic models of capital structure have also occupied finance scholars over the last four decades. Jensen and Meckling (1976), building on the earlier work of Fama \& Miller (1972), pioneered this line of capital structure research. Inefficiencies resulting from the conflict between managers and shareholders on one hand as well as conflict between shareholders and bondholder on the other hand interfere with capital structure amongst other corporate decisions.

This inefficiency is reduced the larger is the fraction of the firm's equity owned by the manager. The implementation of executive stock options as compensation for CEO and managers has been hailed as a potential avenue to align managerial interests to the pursuit of shareholder value maximization \{Jensen (1986), Iyiegbuniwe (2007:30), Brealey, Myers \& Allen (2020)\}. Chen, Chen \& Chu (2014) investigate the impact of executive stock options (ESOs) on managerial efficiency through innovations. Utilizing insights from option pricing theory of Black \&Scholes (1973) and Merton (1973), they find ESO risk incentive (vega) to be positively correlated with all types of corporate innovations. They also find greater ESO risk incentive effects for the product-related innovative activities that are associated more with systematic risk than idiosyncratic risk. The tendency for executives to invest in projects with higher systematic risk is consistent with shareholder value maximization. A similar result on positive stock market reaction (or performance) as an increasing function of CEO stock ownership is documented in Lilienfeld-Toal \& Ruenzi (2014). Holding constant the manager's absolute investment in the firm, increases in the fraction of the firm financed by debt increase the manager's share of the equity and attenuate the loss from the conflict between the manager and shareholders.

The Theoretical Determinants of Capital Structure and 


\section{Firm Characteristics}

Harris \& Raviv [51] explain the conventional factors while Rajan \& Zingales [85], Frank \& Goyal [41, 42], De Jong, et al. [32], Huang \& Ritter [53], Fan, Titman \& Twite [39], Frank \& Shen [43], Demirguc-Kunt, et al [33] and Kim [57] distill these variables into simple cross-sectional models. The factors are as follows:

1. Expected Costs of Financial Distress (or Expected Bankruptcy Costs): Leverage is hypothesized to be a declining function of the expected costs of financial distress (Glover, 2016).

2. Investment Opportunities: As leverage reduces financial flexibility and increases the possibility that positive net present value projects may be bypassed when there is debt overhang, corporate borrowing should have an inverse relationship with growth or investment opportunities.

3. Financial Flexibility: Restrictive covenants are common in most debt contracts. Thus, the greater the need for financial flexibility, the greater the need for debt conservatism.

4. Information Asymmetry: This theory suggests that firms should raise finance through securities that are least prone to information asymmetric problems. Thus, the pecking order financing emerges and suggests retained earnings as the most preferred form of financing. When internal equity is not sufficient to cater for investment needs and external financing is required, then debt is first on the pecking order of external financing. Equity is issued as a last resort.

5. Size: It has been well recognized that bigger firms are less prone to possibility of financial distress perhaps because they are well diversified relative to small firms (Parsons \& Titman [79]). In addition, bankruptcy costs are higher for smaller firms (Titman \& Wessels [91]). Thus, debt has been hypothesized as an increasing function of size according to trade-off model. Pecking order predicts otherwise. Because size can be regarded as a proxy for information asymmetry between firm insiders and the capital markets, large firms are more closely monitored by a large number of analysts and should be capable of issuing informationally more sensitive equity.

6. Asset Tangibility (Collateral): Alleviating the classical bondholder-shareholder conflicts (for instance, Jensen and Meckling, [56]), with more tangible assets, the creditors have an improved guarantee of repayment. Hence, the trade-off theory predicts positive relation between leverage and tangibility. On the other hand, managers of highly levered firms will be less able to consume excessive perquisites, since bondholders more closely monitor such firms (e.g. Grossman and Hart [49]). In general, monitoring costs will be higher for firms with less collateralizable assets, that is, firms with less tangible assets may voluntarily choose higher debt levels to limit consumption of perquisites. This implies a negative relationship between leverage and tangibility (Cerqueiro, Ongena, \& Roszbach [22]).

7. Managerial Entrenchment and Private Benefits: The greater the tendency for managerial entrenchment and consumption of private benefits, the greater the need for debt to provide a disciplinary measure on managers to pursue efficiency over glamorous corporate lifestyle (Jensen [55]; Hart \& Moore [52]).

8. Cash Flows and Liquidity (Profitability): Profitability interacts with financing decisions. Pecking order hypothesizes an inverse relation between leverage and profitability (liquidity) because more profitable, mature firms do not need to borrow to cater for their capital expenditures. However, the trade-off model hypothesizes that more profitable firms will seek to maximize their tax benefits through increased leverage (Cohn, Titman \& Twite [27]).

9. Product Market and Industry Effects: The leverage behavior of firms within an industry may exert significant influence on the choice and magnitude of borrowing by firms. In addition, the riskiness of the firm's products may exert a downward pressure on corporate appetite for debt (Ferres, Ormazabal, Povel $\&$ Sertsios [40]).

10. Herding or peer effects in capital structure: Sometimes, firms tend to follow the capital structure of peer firms. Leary \& Roberts [59] provide evidence that the attributes of peer firms are important determinants of capital structure.

\section{Methodology}

\subsection{Data and Sample}

Based on a careful review of literature and a prior work done by the author, this research is structured to the use of secondary data. The use of secondary data provides a systematic and empirical solution to research problems, by using data which are already in existence. Data for the study were obtained from public sources. Official sources such as the Nigerian Stock Exchange (NSE) and Central Bank of Nigeria (CBN) publications were veritable sources of data for this research. The data relating to market conditions were obtained from the daily official list of the Stock Exchange. Macroeconomic data were obtained from the CBN Statistical Bulletins while the accounting-related information were obtained from the companies' Annual Reports and Accounts (various years). The final selection was in favour of companies with the highest data availability.

The population for this study is the number of quoted companies in Nigeria, whose equities are listed on the Nigerian Stock Exchange (NSE) for the period 1999-2014. The number of such listed (quoted) equities was 164 as at December 2018. Equities are listed under 20 broad industry sectors.

Basically, this study targets all quoted companies on the Nigerian Stock Exchange. However, some adjustments are necessary to derive our sample. First, the sample excludes 
financial services sector because they are subject to specific rules (e.g., Banks and Other Financial Institutions Act (BOFIA, 1991)) and special high-leverage nature of financing is severely affected by exogenous factors (Miller [67]). Therefore, following empirical pattern (such as Rajan \& Zingales [85]), we focus exclusively on non-financial corporations (126 in number). Second, we could not collect the necessary data for many of the smaller firms on the NSE. This adjustment leaves us with a balanced panel of 50 firms over the 1999-2014 period. The year 1999 was chosen as a start year to coincide with the release of the Investment and Securities Act (ISA) 1999 under the then new democratic regime in Nigeria. However, the sample for this study was biased towards a survivalist approach, because given the study period of 1999-2014, some companies' financial results were missing. Table 1 below provides sectoral description of companies selected for the study.

Table 1. Distribution of sample of study.

\begin{tabular}{lllll}
\hline S/N & Sector & Population & Sample & $\begin{array}{l}\text { Sampling } \\
\text { ratio (\%) }\end{array}$ \\
\hline 1 & Agriculture & 6 & 4 & 66 \\
2 & Aviation/Airline & 2 & 1 & 50 \\
3 & Automobile \& Tyre & 3 & 2 & 66 \\
4 & Breweries & 7 & 3 & 43 \\
5 & Building Materials & 7 & 3 & 43 \\
6 & Chemical and Paints & 9 & 4 & 44 \\
7 & Computer & 6 & 1 & 17 \\
8 & Conglomerate & 8 & 4 & 50 \\
9 & Construction/Real & 6 & 3 & 50 \\
10 & Engineering & 3 & 1 & 33 \\
11 & Food and Beverages & 18 & 6 & 33 \\
12 & Health Care & 12 & 5 & 42 \\
13 & Hotels and Tourism & 4 & 1 & 25 \\
14 & Industrial/Domestic & 10 & 4 & 40 \\
15 & Oil and Gas & 9 & 5 & 56 \\
16 & Packaging & 8 & 0 & 0 \\
17 & Publishing & 4 & 2 & 50 \\
18 & Road Transport & 1 & 1 & 100 \\
19 & Textiles & 3 & 0 & 0 \\
& TOTAL & 126 & 50 & 40 \\
\hline
\end{tabular}

Source: Underlying Data from the Nigerian Stock Exchange Factbooks (Various Years).

The researcher is of the opinion that the sample is a representative data and there is no reason to believe that sample selection biases affected the results.

\subsection{Estimation Procedures}

Panel data regression techniques are utilized for the study.

\subsection{Model Specification}

Following empirical approaches therefore,

MODEL I: Impact of firm-specific and industry factors on Debt Ratios of Nigerian Quoted Firms.

The implicit model can be expressed thus:

$\mathrm{D}_{\text {it }}=f\left(\mathrm{NDTS}_{\mathrm{it}}, \mathrm{TANG}_{\mathrm{it}}, \mathrm{GROW}_{\mathrm{it}}, \mathrm{SIZE}_{\mathrm{it}}, \mathrm{VOL}_{\mathrm{it}}, \mathrm{PROF}_{\mathrm{it}}\right.$, $\left.R \& D_{i t}, U Q_{i t}, D F_{i t}, Q_{I C K}, D_{i t} V_{i t}, E_{t}\right)$ Explicitly, with X as vector of explanatory variables,

$$
\mathrm{D}_{\mathrm{it}}=\beta_{0}+\beta_{\mathrm{x}} \mathrm{X}_{\mathrm{it}}+\varepsilon
$$

$\mathrm{H}_{01}: \beta$ 's $=0$; alternatively, $\mathrm{H}_{11}: \beta$ 's $\neq 0$.

Where $D_{\text {it }}$ represents the leverage measure for firm $i$ at time $t$. For all the variables, except expected inflation, the subscripts it can be interpreted that each exogenous factor is for firm $i$ at time $t$. The independent variables could be taken contemporaneously or lagged one period. Both methods are acceptable in empirical corporate finance.

Debt ratio defined as "the ratio of total liabilities to total liabilities plus equity" is the chosen leverage measure for this study. This measure is equivalent to the "total liabilities to assets ratio" being advocated by Welch [92, 93]. Three measures of debt ratio are employed namely: Book Leverage, Market leverage capturing only financial liabilities $\left(\mathrm{ML} 1_{\mathrm{t}}\right)$ and Market leverage capturing all liabilities in the balance sheet $\left(M L 2_{t}\right) . M L 1_{t}$ is the financial leverage ratio while $M L 2_{t}$ is the total leverage ratio. All the chosen leverage measures are stock-based methods. Because of space constraint, all the explanatory variables are defined in Table 3 . The regression parameters ( $\beta$ 's) are stated in column five of Table 3.

NDTS represents non-debt tax shield inspired by DeAngelo \& Masulis [30].

TANG represents the tangibility of the firm's assets, a collateral measure of debt capacity.

GROWTH is measured by the market-to-book value of the firm's stock, a measure of growth opportunities of the firm. An alternative measure is the $Q$ ratio measured as the marketto-book value of the firm's assets.

SIZE represented by the natural log of sales (LNS). LNS is a common proxy for firm size. $V O L$ is the volatility of earnings, a measure of business risk. [Risk may also be measured by the volatility of stock returns or stock prices as in Frank \& Goyal [42], Olowe [75, 76], or volatility of firm's assets as in Choi and Richardson [26].

PROF represents profitability, measured by the Return on Assets (ROA).

$R \& D$ means research and development expenditure (scaled by total assets), a proxy for uniqueness of assets and also intangibility of assets. $U N Q$ for asset uniqueness. A business risk proxy for the industry.

$D E F$ is a measure of financing deficit, i.e., requirement for external finance because retained earnings are insufficient to cater for planned capital expenditures.

The financing deficit term is an added factor as inspired by Frank \& Goyal [41] and utilized by many authors to test the pecking order theory.

QUICK represents the quick or acid test ratio. A stricter measure of liquidity relative to the current ratio.

$D I V$ represents dividend payout ratio. Dividend-paying status of firms is a critical factor that underscores the degree of information asymmetry between insiders and outside financiers. It also captures agency effects in financing decisions. Used in Barakat and Rao [15] to underscore the relative importance of dividend income vis-à-vis interest income.

$E_{t}$ represents expected inflation, the only macroeconomic 
factor to be included in the model. Frank \& Goyal [42] provide strong evidence in support of a positive relationship between leverage and expected inflation.

The null hypothesis is that the $\beta$ 's are not significantly different from zero, i.e., $\mathrm{H}_{01}$ : $\beta$ 's $=0$; alternatively, $\mathrm{H}_{11}$ : $\beta$ 's $\neq$ 0 . In other words, firm-specific characteristics do not exert significant impact on corporate debt ratios.

Definition of Variables

Table 2. Determinants of Capital Structure and their Expected Signs and Magnitudes.

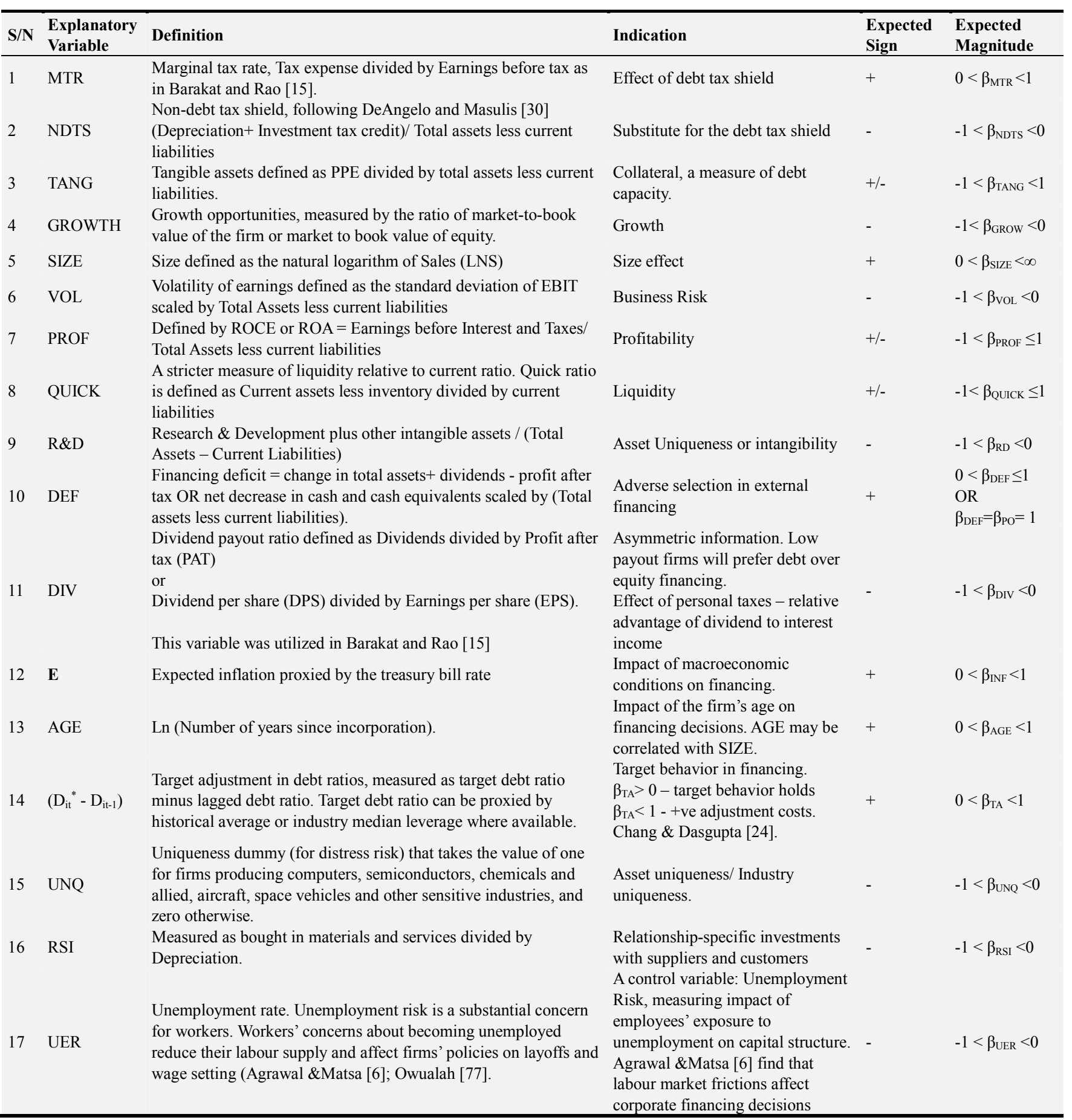

Source: Paseda [80]

\section{Empirical Results}

This section presents the empirical analysis and results of the study. Again, the research aim is to investigate the impact of firm-specific factors on the capital structure decisions of Nigerian quoted firms. Table 3 presents the summary statistics. The regression results follow in different tables 4-11. 
Table 3. Summary Statistics Of Variables Used In The Study.

\begin{tabular}{lllllllll}
\hline VAR & Mean & Median & Maximum & Minimum & Std. Dev. & Skewness & Kurtosis & Jarque-Bera \\
\hline BLT & 0.6870 & 0.6053 & 9.2630 & -0.3396 & 0.5595 & 8.1587 & 100.46 & 16255616.00 \\
ML1T & 0.2729 & 0.1902 & 0.9959 & 0.0000 & 0.2605 & 0.8387 & 2.64 & 4903.77 \\
ML2T & 0.4656 & 0.4284 & 0.9970 & 0.0525 & 0.2558 & 0.3316 & 1.97 & 2495.79 \\
DMS & 0.7545 & 0.8092 & 1.0453 & 0.0000 & 0.2120 & -1.3618 & 4.90 & 18328.52 \\
MTR & 0.2855 & 0.3016 & 13.3333 & -16.3462 & 1.0649 & 2.0583 & 153.92 & 37944563.00 \\
NDTS & 0.1179 & 0.0771 & 1.3270 & -0.9339 & 0.1547 & 2.3142 & 18.39 & 429669.30 \\
TANG & 0.6241 & 0.6350 & 3.0970 & -4.5480 & 0.5432 & -2.8335 & 30.96 & 1355217.00 \\
GROW & 1.6307 & 1.7763 & 96.4290 & -1090.00 & 40.2090 & -25.2730 & 681.22 & 770000000 \\
SIZE & 15.2322 & 15.4420 & 20.2930 & 0.0000 & 2.9717 & -2.5688 & 13.60 & 231119.40 \\
VOL & 0.5036 & 0.1062 & 16.4410 & -2.2449 & 2.1285 & 6.3166 & 42.23 & 2826856.00 \\
PROF & 0.2133 & 0.2147 & 4.7059 & -8.3240 & 0.6764 & -4.2574 & 60.14 & 5556220.00 \\
QUICK & 0.6925 & 0.6279 & 2.9950 & 0.0000 & 0.4181 & 1.7562 & 7.85 & 59735.46 \\
RD & 0.0225 & 0.0000 & 0.8929 & 0.0000 & 0.0971 & 6.3678 & 47.35 & 3544312.00 \\
UNQ & 0.6195 & 1.0000 & 1.0000 & 0.0000 & 0.4855 & -0.4924 & 1.24 & 6756.17 \\
DEF & 0.2103 & 0.1331 & 14.2350 & -4.3168 & 0.8064 & 7.4961 & 132.76 & 28402908.00 \\
DIV & 0.4150 & 0.3723 & 7.0833 & 0.0000 & 0.4746 & 4.5288 & 55.21 & 4674762.00 \\
EINF & 0.1119 & 0.1177 & 0.1888 & 0.0400 & 0.0401 & 0.0681 & 2.21 & 1075.42 \\
AGE & 3.7149 & 3.7612 & 4.5109 & 0.3367 & 0.4040 & -1.8264 & 11.37 & 138787.60 \\
DDTA & 0.0031 & -0.0011 & 1.7132 & -4.6197 & 0.3464 & -4.2622 & 56.51 & 4887965.00 \\
\hline
\end{tabular}

SOURCE: Author's Computation from Microsoft Excel.

Table 4. Leverage regressions.

\begin{tabular}{|c|c|c|c|c|c|c|c|c|c|}
\hline DEP. VAR. & BLT & & & ML1T & & & ML2T & & \\
\hline EXP.VAR & COEFF. & STD.ERR & t-STAT & COEFF. & STD.ERROR & t-STAT & COEFF. & STD.ERROR & t-STAT \\
\hline $\mathrm{C}$ & 0.4873 & 0.008258 & 59.01681 & 0.789403 & 0.010381 & 76.04495 & 0.487334 & 0.008258 & 59.01681 \\
\hline $\begin{array}{l}\text { BLT(-1), ML1T(-1), } \\
\text { ML2T(-1) }\end{array}$ & 0.7496 & 0.000405 & 1852.684 & 0.735424 & 0.000558 & 1317.096 & 0.749564 & 0.000405 & 1852.684 \\
\hline MTR & -0.0007 & 0.000130 & -5.706789 & -0.004102 & 0.000149 & -27.61393 & -0.000743 & 0.000130 & -5.706789 \\
\hline NDTS & 0.1114 & 0.000568 & 196.0501 & 0.050328 & 0.000889 & 56.61995 & 0.111402 & 0.000568 & 196.0501 \\
\hline TANG & -0.0274 & 0.000175 & -156.4958 & -0.019523 & 0.000202 & -96.75458 & -0.027389 & 0.000175 & -156.4958 \\
\hline GROW & $-1.93 \mathrm{E}-05$ & $1.23 \mathrm{E}-05$ & -1.560318 & $-5.04 \mathrm{E}-05$ & $1.25 \mathrm{E}-05$ & -4.038616 & $-1.93 \mathrm{E}-05$ & $1.23 \mathrm{E}-05$ & -1.560318 \\
\hline SIZE & -0.0038 & $4.05 \mathrm{E}-05$ & -93.95959 & -0.011532 & 7.82E-05 & -147.5077 & -0.003806 & $4.05 \mathrm{E}-05$ & -93.95959 \\
\hline VOL & 0.0002 & $6.95 \mathrm{E}-05$ & 3.202441 & -0.007034 & 7.77E-05 & -90.49038 & 0.000223 & $6.95 \mathrm{E}-05$ & 3.202441 \\
\hline PROF & -0.0172 & 0.000227 & -75.90996 & -0.007896 & 0.000150 & -52.61294 & -0.017206 & 0.000227 & -75.90996 \\
\hline QUICK & -0.0403 & 0.000229 & -176.0211 & -0.049549 & 0.000204 & -243.3950 & -0.040295 & 0.000229 & -176.0211 \\
\hline $\mathrm{RD}$ & 0.0872 & 0.001142 & 76.35822 & 0.134748 & 0.001303 & 103.3826 & 0.087203 & 0.001142 & 76.35822 \\
\hline UNQ & 0.0151 & 0.000149 & 101.4586 & -0.005559 & 0.000194 & -28.70477 & 0.015089 & 0.000149 & 101.4586 \\
\hline DEF & -0.0093 & 0.000137 & -67.69795 & -0.011206 & 0.000278 & -40.31463 & -0.009253 & 0.000137 & -67.69795 \\
\hline DIV & -0.0407 & 0.000181 & -224.9471 & -0.036335 & 0.000232 & -156.8584 & -0.040677 & 0.000181 & -224.9471 \\
\hline EINF & 0.6453 & 0.010643 & 60.63348 & 0.908912 & 0.016686 & 54.47209 & 0.645301 & 0.010643 & 60.63348 \\
\hline AGE & 0.0098 & 0.000176 & 55.62885 & 0.010347 & 0.000255 & 40.64010 & 0.009789 & 0.000176 & 55.62885 \\
\hline DDTA & 0.0168 & 0.000354 & 47.49500 & -0.009761 & 0.000360 & -27.10674 & 0.016825 & 0.000354 & 47.49500 \\
\hline ADJ. $R^{2}$ & 0.9998 & & & 0.999206 & & & 0.999770 & & \\
\hline $\begin{array}{l}\text { ADJ. R² } \\
\text { (UNWEIGHTED) }\end{array}$ & 0.3154 & & & 0.676300 & & & 0.71998 & & \\
\hline S.E. of Reg & 0.4479 & & & 0.144244 & & & 0.132063 & & \\
\hline F- Stat & 819052 & & & 1792697. & & & 6190619. & & \\
\hline Prob (F-Statistic) & 0.0000 & & & 0.000000 & & & 0.000000 & & \\
\hline Durbin-Watson. & 2.0784 & & & 1.94244 & & & 1.9725 & & \\
\hline
\end{tabular}

Source: Author's analysis. **Significant at $1 \%$ and $5 \%$

From the summary statistics in Table 3 , several facts can be deduced as statistical features of the variables utilized for the study. First, the relationship between the three measures of leverage is revealing of the relative weights of financial to non-financial debt in corporate balance sheets. For instance, the relative means of market leverage measure I which captures only financial liabilities relative to book leverage is suggestive that about 40 percent of corporate liabilities are financial while the balance of 60 percent are non-financial. In other words, book leverage ratios are often 2.52 times as high as market-based leverage ratio I (ML1). The magnitude of book leverage over market leverage is most pronounced in firms and industries where the book equity is depressed or even negative ((e.g., agriculture, automobile and breweries (2005-2007)). The relative ratio of Market leverage I to Market Leverage II suggests a $56 \%$ percentage of liabilities represented by financial debt while the balance of 41 percent are non-financial liabilities. The conventional reason for higher book-based leverage measure relative to market-based leverage measure is that the book values of equity might, on 
average, be less than the market values of equity. The relative ratios of the leverage median statistics reveal that nonfinancial liabilities could in fact be representing 69 percent of corporate liabilities when ML1 and BL are compared. However, the comparison between ML1 and ML2 median values moderates the proportion of non-financial liabilities to total corporate liabilities to 56 percent. Thus, before any rigorous analysis, it is clear that non-financial liabilities are significant sources of financing for modern corporations in Nigeria. The typical components of non-financial liabilities are spontaneous sources of credit between business contact groups such as financing by trade credit or vendor financing as well as other accrued obligations. The trade credit phenomenon is observable in both developed and developing countries (Barrot [17]).

Further, the comparison between minimum and maximum values of leverage indicates that there is wide heterogeneity in how Nigerian listed firms are financed while some firms did not utilize financial debt for some or nearly through the study period, given the zero minimum value ("zero-leverage phenomenon"). The heterogeneity is also buttressed by the standard deviation of book leverage. Specifically, the size factor plays a role in the relative mix of financial and nonfinancial obligations. Large firms tend to have relatively more of their total liabilities in financial obligations than small firms. Moreover, large firms tend to have relatively less of their total debt in short-term obligations than small firms. Small firms rely disproportionately more on trade credit and delay (or lag) in meeting obligations to employees and other non-financial stakeholders.

Firm characteristics can be ranked in this order in terms of their mean values namely: Size, firm age, growth opportunities, liquidity as measured by acid-test or quick ratio, asset tangibility, uniqueness, volatility, dividend payout policy (in terms of high versus low payout), profitability, financing deficit, non-debt tax shield, and Research and Development (R\&D). Among the firm factors, the $R \& D$ showed the least dispersion around the mean as can be observed from its standard deviation.

Table 5. Pecking order and target adjustment models.

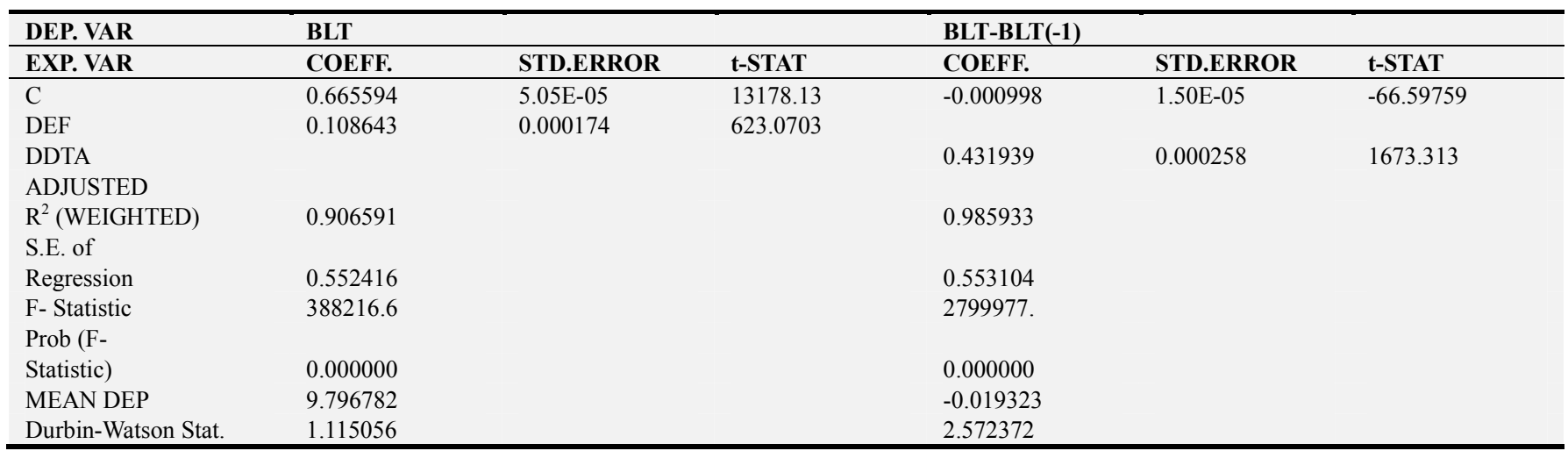

Source: Author's analysis (2016).

Table 5 above presents the simple test of the pecking order and target adjustment models with explanatory variables of financing deficit (DEF) and target adjustment in debt ratios (DDTA) respectively. Given positive DEF and DDTA coefficients of 0.1086 and 0.4319 respectively which are both significant at $1 \%$ level, the pecking order and target adjustment models cannot be rejected in the Nigerian market.

Table 6. Regression Results of the Impact of Firm Characteristics on Book Leverage (BL) Ratio.

\begin{tabular}{|c|c|c|c|c|}
\hline Variable & Coefficient & Std. Error & t-Statistic & Prob. \\
\hline $\mathrm{C}$ & 0.876872 & 0.001206 & 726.9440 & 0.0000 \\
\hline BLT(-1) & 0.407608 & 0.000372 & 1096.007 & 0.0000 \\
\hline NDTS & 0.026711 & 0.001442 & 18.52950 & 0.0000 \\
\hline TANG & -0.115164 & 0.000238 & -484.0764 & 0.0000 \\
\hline GROW & $-1.26 \mathrm{E}-05$ & $1.05 \mathrm{E}-05$ & -1.205408 & 0.2281 \\
\hline SIZE & -0.047144 & $5.64 \mathrm{E}-05$ & -836.3237 & 0.0000 \\
\hline VOL & -0.046709 & $6.46 \mathrm{E}-05$ & -722.5965 & 0.0000 \\
\hline QUICK & -0.208931 & 0.000245 & -853.1059 & 0.0000 \\
\hline $\mathrm{RD}$ & 0.146785 & 0.001284 & 114.3394 & 0.0000 \\
\hline UNQ & -0.119176 & 0.000218 & -547.2867 & 0.0000 \\
\hline DEF & 0.061986 & 0.000392 & 158.3106 & 0.0000 \\
\hline DIV & -0.060888 & 0.000315 & -193.5494 & 0.0000 \\
\hline EINF & 0.200743 & 0.001893 & 106.0477 & 0.0000 \\
\hline AGE & $\begin{array}{l}0.148642 \\
\text { Weighted Statistics }\end{array}$ & 0.000283 & 525.9575 & 0.0000 \\
\hline R-squared & 0.998434 & Mean dependent var & & 11.07570 \\
\hline
\end{tabular}




\begin{tabular}{|c|c|c|c|c|}
\hline Variable & Coefficient & Std. Error & t-Statistic & Prob. \\
\hline Adjusted R-squared & 0.998433 & S.D. dependent var & & 53.92684 \\
\hline S.E. of regression & 0.461677 & Sum squared resid & & 8511.954 \\
\hline F-statistic & 1818397. & Durbin-Watson stat & & 1.182224 \\
\hline Prob(F-statistic) & $\begin{array}{l}0.000000 \\
\text { Unweighted Statistics }\end{array}$ & & & \\
\hline R-squared & 0.302536 & Mean dependent var & & 0.688574 \\
\hline Sum squared resid & 8750.866 & Durbin-Watson stat & & 2.064550 \\
\hline
\end{tabular}

**Significant at $1 \%$ and $5 \%$

From the above results in Table 6, all the variables, except growth, are significant at 1 percent significance level. Debt usage is a declining function of tangibility (TANG), growth opportunities (GROW), size (SIZE), volatility of earnings (VOL), profitability (PROF), liquidity

(QUICK), uniqueness of industry (UNQ) and dividend payout ratio (DIV). Book leverage increases with non-debt tax shields (NDTS), asset intangibility (RD), financing deficit, age and expected inflation (EINF). The signs and magnitude of the coefficients are more consistent with the pecking order theory than the trade-off theory of financing in terms of the number of coefficients tally with theoretical prediction. More specifically, the (negative) signs of the coefficients of profitability, liquidity, tangibility, size and financing deficit are consistent with the pecking order while the trade-off predicts otherwise. The positive relationship between leverage and non-debt tax shields is inconsistent with the debt substitution hypothesis of DeAngelo-Masulis [30] framework. Rather, the positive relation might be indicative of the collateral value of assets. The availability of alternative tax shelters does not reduce the tax-incentives to borrow. The inverse relationships between leverage and tangibility as well as leverage and size are consistent with agency effects wherein smaller firms with less tangible assets voluntarily choose higher debt levels to limit consumption of perquisites. In addition, the expected inflation as a proxy of macroeconomic conditions has a positive relation with leverage. Expectations of decline in the purchasing power of the naira exerts upward pressure on corporate borrowing behaviour, thus aggressive debt usage by firms would be consistent with the wealth-redistribution effect of inflation. At inflationary periods, the time value of money reduces the value of liabilities ceteris paribus, that is, borrowers gain while lenders lose. However, it is clear that the coefficient of multiple determination $\left(\mathrm{R}^{2}\right)$, which is the statistical measure of the goodness of fit of the regression, is abysmally low at 30 percent. The Durbin-Watson test for serial correlation of variables is, however, satisfactory at 2.06 . The inclusion of the lag of the dependent variable helps to overcome the problem of autocorrelation. Given low $\mathrm{R}^{2}$, the model requires modification to period-weighted regression in order to produce meaningful analysis of capital structure choice by Nigerian firms.

It is also clear that debt ratio is strongly affected by prior borrowing behaviour.

Table 7. Determinants of Capital Structure-Market Leverage 1 Regression I.

\begin{tabular}{|c|c|c|c|c|}
\hline \multicolumn{5}{|c|}{ Dependent Variable: ML1T } \\
\hline \multicolumn{5}{|c|}{ Total pool (balanced) observations: 39950} \\
\hline Variable & Coefficient & Std. Error & t-Statistic & Prob. \\
\hline $\mathrm{C}$ & 0.148090 & 0.009493 & 15.60071 & 0.0000 \\
\hline ML1T(-1) & 0.729715 & 0.003217 & 226.8397 & 0.0000 \\
\hline NDTS & 0.043586 & 0.005017 & 8.687021 & 0.0000 \\
\hline TANG & -0.014812 & 0.001508 & -9.823051 & 0.0000 \\
\hline GROW & $-3.90 \mathrm{E}-05$ & $1.89 \mathrm{E}-05$ & -2.057894 & 0.0396 \\
\hline SIZE & -0.009677 & 0.000461 & -20.98867 & 0.0000 \\
\hline VOL & -0.003685 & 0.000555 & -6.633788 & 0.0000 \\
\hline PROF & -0.007643 & 0.001152 & -6.632157 & 0.0000 \\
\hline QUICK & -0.045548 & 0.001944 & -23.43052 & 0.0000 \\
\hline $\mathrm{RD}$ & 0.133656 & 0.008074 & 16.55330 & 0.0000 \\
\hline UNQ & 0.006171 & 0.001877 & 3.287893 & 0.0010 \\
\hline DEF & -0.010882 & 0.000980 & -11.10641 & 0.0000 \\
\hline DIV & -0.041997 & 0.001736 & -24.18540 & 0.0000 \\
\hline EINF & 0.137145 & 0.019454 & 7.049744 & 0.0000 \\
\hline AGE & 0.029778 & 0.002106 & 14.14188 & 0.0000 \\
\hline R-squared & 0.664573 & Mean dependent var & & 0.273663 \\
\hline Adjusted R-squared & 0.664456 & S.D. dependent var & & 0.260540 \\
\hline S.E. of regression & 0.150921 & Akaike info criterion & & -0.943749 \\
\hline Sum squared resid & 909.6023 & Schwarz criterion & & -0.940521 \\
\hline Log likelihood & 18866.38 & Hannan-Quinn criter. -0.942727 & & \\
\hline F-statistic & 5651.596 & Durbin-Watson stat 1.929436 & & \\
\hline Prob(F-statistic) & 0.000000 & & & \\
\hline
\end{tabular}

** Significant at $1 \%$ and $5 \%$ 
Table 8. Market Leverage 1 Regression I.

\begin{tabular}{|c|c|c|c|c|}
\hline \multicolumn{5}{|c|}{ Dependent Variable: ML1T } \\
\hline \multicolumn{5}{|c|}{ Method: Pooled EGLS (Period weights) } \\
\hline Variable & Coefficient & Std. Error & t-Statistic & Prob. \\
\hline $\mathrm{C}$ & 0.142599 & 0.000988 & 144.2911 & 0.0000 \\
\hline ML1T(-1) & 0.739901 & 0.000415 & 1783.654 & 0.0000 \\
\hline NDTS & 0.044202 & 0.000629 & 70.32025 & 0.0000 \\
\hline TANG & -0.015393 & 0.000132 & -116.4674 & 0.0000 \\
\hline GROW & $-1.95 \mathrm{E}-05$ & $6.88 \mathrm{E}-06$ & -2.838769 & 0.0045 \\
\hline SIZE & -0.009033 & 4.91E-05 & -184.0978 & 0.0000 \\
\hline VOL & -0.003110 & $8.60 \mathrm{E}-05$ & -36.16081 & 0.0000 \\
\hline PROF & -0.008848 & 0.000196 & -45.24902 & 0.0000 \\
\hline QUICK & -0.044933 & 0.000107 & -418.6882 & 0.0000 \\
\hline $\mathrm{RD}$ & 0.131144 & 0.002921 & 44.89437 & 0.0000 \\
\hline UNQ & 0.006240 & 0.000165 & 37.75969 & 0.0000 \\
\hline DEF & -0.012463 & 0.000149 & -83.83216 & 0.0000 \\
\hline DIV & -0.040086 & 0.000196 & -204.1230 & 0.0000 \\
\hline EINF & 0.117515 & 0.001158 & 101.4630 & 0.0000 \\
\hline AGE & 0.028328 & 0.000171 & 165.2988 & 0.0000 \\
\hline & Weighted Statistics & & & \\
\hline R-squared & 0.999794 & \multicolumn{2}{|l|}{ Mean dependent var } & 10.35635 \\
\hline Adjusted R-squared & 0.999794 & \multicolumn{2}{|l|}{ S.D. dependent var } & 241.3654 \\
\hline S.E. of regression & 0.149224 & \multicolumn{2}{|l|}{ Sum squared resid } & 889.2645 \\
\hline F-statistic & 13864289 & \multicolumn{2}{|l|}{ Durbin-Watson stat } & 1.494301 \\
\hline \multirow[t]{2}{*}{ Prob(F-statistic) } & 0.000000 & & & \\
\hline & Unweighted Statistics & & & \\
\hline R-squared & 0.664432 & \multicolumn{2}{|l|}{ Mean dependent var } & 0.273663 \\
\hline Sum squared resid & 909.9846 & \multicolumn{2}{|l|}{ Durbin-Watson stat } & 1.948980 \\
\hline
\end{tabular}

** Significant at $1 \%$ and $5 \%$

Tables 7 and 8 show that all the variables are significant at $1 \%$ except growth which is significant at 5\% in Table 7. Market debt ratio is a declining function of eight explanatory variables namely: tangibility, growth options, size, volatility, profitability, liquidity, financing deficit and dividend payout policy while it increases with non-debt tax shield, asset intangibility (R\&D and other intangibles), uniqueness, expected inflation and age. The inverse relationships between leverage and tangibility as well as leverage and size are consistent with agency effects wherein smaller firms with less tangible assets voluntarily choose higher debt levels to limit consumption of perquisites. However, the $\mathrm{R}^{2}$ improved from 30 percent to $66 \%$ implying that the cross-sectional and timeseries variations in corporate borrowing behaviour are better explained by firm-specific and industry factors when leverage is measured using market values. The direct relation with age and expected inflation can be interpreted thus

i) Older firms borrow more than their younger counterparts. The business reputation built over time reduces ex ante costs or probability of financial distress, thereby increasing debt capacity consistent with the trade-off model.

ii) Inflation has a possible wealth redistribution effect. Credit arrangements un-adjusted for time value of money or inflation exert pressure on the value of receivables (assets) on lenders' balance sheets. Therefore, creditors suffer the inflation effect while debtors gain holding inflation premium in debt pricing constant. In other words, inflation transfers wealth from creditors to borrowers.

Table 9. Firm-Specific and Industry Determinants of Borrowing-Market Leverage 2 Regression.

\begin{tabular}{|c|c|c|c|c|}
\hline \multicolumn{5}{|c|}{ Dependent Variable: ML2T } \\
\hline Variable & Coefficient & Std. Error & t-Statistic & Prob. \\
\hline $\mathrm{C}$ & 0.108824 & 0.008878 & 12.25760 & 0.0000 \\
\hline ML2T(-1) & 0.740249 & 0.003117 & 237.4661 & 0.0000 \\
\hline NDTS & 0.103260 & 0.004719 & 21.88376 & 0.0000 \\
\hline TANG & -0.024800 & 0.001417 & -17.49745 & 0.0000 \\
\hline GROW & $-3.02 \mathrm{E}-05$ & $1.78 \mathrm{E}-05$ & -1.700931 & 0.0890 \\
\hline SIZE & -0.003312 & 0.000430 & -7.704318 & 0.0000 \\
\hline PROF & -0.019310 & 0.001085 & -17.80250 & 0.0000 \\
\hline QUICK & -0.033719 & 0.001808 & -18.64936 & 0.0000 \\
\hline $\mathrm{RD}$ & 0.061878 & 0.007576 & 8.167602 & 0.0000 \\
\hline UNQ & 0.023517 & 0.001785 & 13.17167 & 0.0000 \\
\hline DEF & -0.013557 & 0.000921 & -14.71553 & 0.0000 \\
\hline DIV & -0.046280 & 0.001639 & -28.23573 & 0.0000 \\
\hline EINF & 0.141775 & 0.018419 & 7.697214 & 0.0000 \\
\hline
\end{tabular}




\begin{tabular}{|c|c|c|c|c|}
\hline \multicolumn{5}{|c|}{ Dependent Variable: ML2T } \\
\hline Variable & Coefficient & Std. Error & t-Statistic & Prob. \\
\hline R-squared & 0.693473 & Mean dependent var & & 0.466432 \\
\hline Adjusted R-squared & 0.693366 & S.D. dependent var & & 0.255786 \\
\hline S.E. of regression & 0.141641 & Akaike info criterion & & -1.070673 \\
\hline Sum squared resid & 801.1778 & Schwarz criterion & & -1.067446 \\
\hline Log likelihood & 21401.69 & Hannan-Quinn criter. -1.069651 & & \\
\hline F-statistic & 6453.381 & Durbin-Watson stat 1.955631 & & \\
\hline Prob(F-statistic) & 0.000000 & & & \\
\hline
\end{tabular}

**Significant at $1 \%$ and $5 \%$

Table 10. Market Leverage 2 Regression (Period weighted).

\begin{tabular}{|c|c|c|c|c|}
\hline \multicolumn{5}{|c|}{ Dependent Variable: ML2T } \\
\hline \multicolumn{5}{|c|}{ Method: Pooled EGLS (Period weights) } \\
\hline \multicolumn{5}{|c|}{ Cross-sections included: 50} \\
\hline \multicolumn{5}{|c|}{ Total pool (balanced) observations: 39950} \\
\hline Variable & Coefficient & Std. Error & t-Statistic & Prob. \\
\hline $\mathrm{C}$ & 0.104381 & 0.001057 & 98.78798 & 0.0000 \\
\hline ML2T(-1) & 0.740216 & 0.000402 & 1840.926 & 0.0000 \\
\hline NDTS & 0.102521 & 0.000514 & 199.4507 & 0.0000 \\
\hline TANG & -0.025744 & $8.66 \mathrm{E}-05$ & -297.1455 & 0.0000 \\
\hline GROW & $-5.19 \mathrm{E}-05$ & $1.54 \mathrm{E}-05$ & -3.361835 & 0.0008 \\
\hline SIZE & -0.003475 & $5.06 \mathrm{E}-05$ & -68.67239 & 0.0000 \\
\hline VOL & 0.001737 & 5.61E-05 & 30.95942 & 0.0000 \\
\hline PROF & -0.017972 & 0.000219 & -82.18958 & 0.0000 \\
\hline QUICK & -0.033217 & 0.000221 & -150.1836 & 0.0000 \\
\hline $\mathrm{RD}$ & 0.052356 & 0.001508 & 34.72712 & 0.0000 \\
\hline UNQ & 0.021712 & 0.000233 & 93.22011 & 0.0000 \\
\hline DEF & -0.012175 & 0.000169 & -71.98170 & 0.0000 \\
\hline DIV & -0.048314 & 0.000283 & -170.4400 & 0.0000 \\
\hline EINF & 0.137678 & 0.001808 & 76.15711 & 0.0000 \\
\hline AGE & $\begin{array}{l}0.024708 \\
\text { Weighted Statistics }\end{array}$ & 0.000279 & 88.46639 & 0.0000 \\
\hline R-squared & 0.999639 & Mean dependent var & & 3.195192 \\
\hline Adjusted R-squared & 0.999638 & S.D. dependent var & & 19.45916 \\
\hline S.E. of regression & 0.140228 & Sum squared resid & & 785.2800 \\
\hline F-statistic & 7888986 & Durbin-Watson stat & & 1.673997 \\
\hline Prob(F-statistic) & $\begin{array}{l}0.000000 \\
\text { Unweighted Statistics }\end{array}$ & & & \\
\hline R-squared & 0.693350 & Mean dependent var & & 0.466432 \\
\hline Sum squared resid & 801.5011 & Durbin-Watson stat & & 1.954358 \\
\hline
\end{tabular}

**Significant at $1 \%$ and $5 \%$

From the Tables 9 and 10 above, all the variables are significant at 1 percent level. However, growth is significant at 10 percent level of significance. Market leverage declines with tangibility, size, liquidity, profitability, dividend payout ratio meaning that bigger firms with safe tangible assets and abundant liquid assets borrow less. Sticky dividend policies constrain firms from borrowing when cash flows from operations are insufficient to cater for capital expenditures. Such firms would rather sell marketable securities to retire debt. All these practices are consistent with pecking order financing. The results obtained here are similar with those presented in Tables 9 and 10.

Unweighted $\mathrm{R}^{2}$ approximates 70 percent, implying that the unaccounted factors capture merely 30 percent of crosssectional and time-series variation in market leverage. Thus, with respect to the hypothesis, it is safe to reject the null hypothesis that firm-specific (and industry) characteristics do not influence corporate borrowing decisions. Firm-specific and industry characteristics are more effective in influencing market-based leverage ratios than book leverage.

\section{Robustness Checks on Empirical Results}

To confirm that the impact of the chosen firm-specific characteristics on corporate borrowing behavior in Nigeria is not a fluke or sensitive to omission of critical variables, an attempt is made here to include other possible determinants of leverage such as measures of non-financial stakeholders, tax position, supply-side and/or macroeconomic variables. The included control variables are marginal tax rate (MTR); unemployment rate (UER); unionization ratio (UNR); staff cost (STC); relationship-specific investments (RSI); rating dummy (RAT) as a measure of debt market access; credit to private sector (CPS) as a measure of financial intermediation; monetary policy regime or rate (MPR) to underscore monetary policy tightness or easing; term spread (TS); equity 
market capitalization (EMC); All-Share index (ASI); government borrowing to GDP (GB) to ascertain possibility of crowding out of private-sector borrowing [Badoer \&
James (2016)]; and growth in GDP. The empirical results are presented in table 11 below.

Table 11. Impact of Control Variables on Market Leverage (Regression Result).

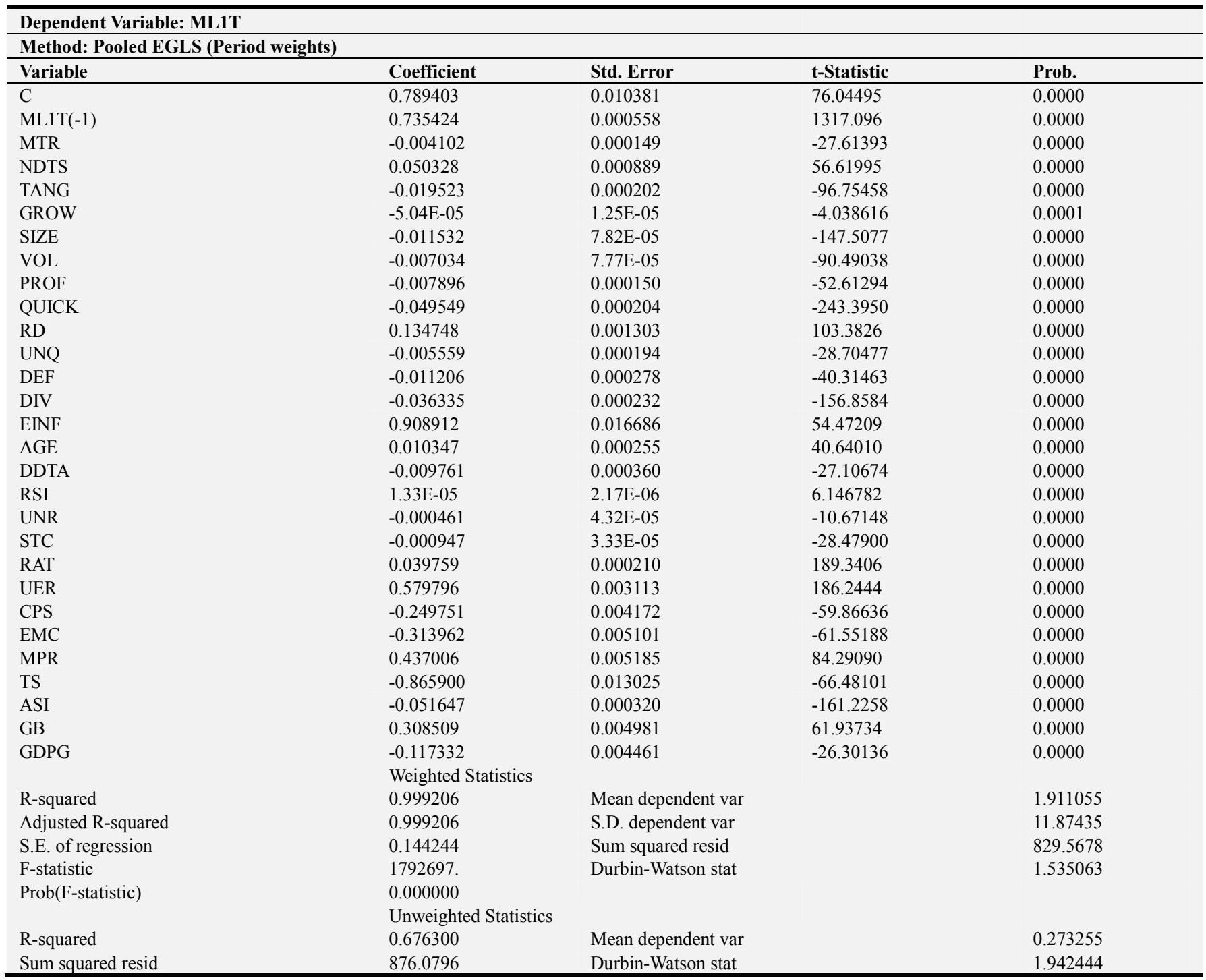

**Significant at $1 \%$

The relevant dependent variable is the market leverage ratio (ML1t) which captures only financial liabilities. All the non-financial stakeholder variables and supply-side factors are significant at 1 percent. However, the joint significance of these other sets of control variables do not undermine the several and joint impact of the firm-specific factors on leverage given the $\mathrm{R}^{2}$ of 68 percent as compared with $\mathrm{R}^{2}$ of 66 percent in Tables 8 and 9 which had firm-specific factors as sole determinants.

\section{Theoretical and Practical Implications of Findings}

In Nigeria, corporate borrowing is explained better by asymmetric information than by other imperfections such as taxes, market timing or agency effects. This is revealed by the signs of the relations between leverage and conventional factors such as asset tangibility, earnings volatility, dividend payout ratio, liquidity, profitability, size and industry uniqueness. The debt levels that this study's model generates are lower than those predicted in trade-off models but in line with the ones observed in Nigerian corporate sector. The pecking order view suggests that the adverse selection costs of equity are large enough to render other costs and benefits of debt second order.

Non-debt tax shelters play a fairly minor role in capital structure choice. The study could not establish any inverse relation between leverage and non-debt tax shields (such as depreciation, amortization, investment allowances, tax-loss carry forwards and backwards, etc). The positive relationship between non-debt tax shields and leverage rather points to 
greater debt capacity instead of an attempt to substitute debt for alternative tax shields - this is the complementary hypothesis of non-debt tax shields.

Next, even though it is conventional - especially in tradeoff models - to assume or infer that debt capacity is an increasing function of the value of tangible "assets in place" so that the higher the collateral value of a firm's assets-inplace, the greater the firm's ability to borrow, the results from this study counter that notion. Asset tangibility has no positive impact on leverage. The inverse relationship between corporate borrowing and the value of pledgeable assets in place implies the presence of "non-collateral" based debt transactions in Nigeria. Indeed, lending institutions in the country have some credit products that do not require any form of collateral as security for credit facilities. Such practices are sometimes called "naked" or "unsecured" or "uncollateralized" lending. The results are consistent with the findings of Machokoto, Areneke \& Ibrahim [63] but counter the findings of Maes, Dewaelheyns, Fuss \& van Hulle [64] who report a strong positive relationship between pledgeable assets and access to short-term debt especially for firms exposed to the risk of distant export markets.

The inverse relationship between debt ratio and growth opportunities reported in this study is consistent with Myers [70] debt overhang analysis in the face of risky debt and valuable investment opportunities. Debt overhang occurs when the debt burden is so huge that the firm cannot raise additional finance to cater for its future projects, a situation which forces the firm to bypass valuable investment programs (so called under-investment problem).

The explanatory power of the explanatory variables of capital structure is sensitive to the choice of estimation techniques. The three types of capital structure variation are cross-firm, cross-industry and within-firm through time. The challenge therefore is to seek out appropriate models of capital structure choice. This work is an attempt and outcome of that challenge. Dynamic models of capital structure choice that, for instance, incorporate lagged values of the debt ratios of firms perform better. The dynamic models can incorporate aspects of the competing theories of capital structure as attempted in this study.

There is support for the target adjustment hypothesis in Nigeria in line with DeAngelo \& Roll [31]. Target adjustment behavior explains the instability of firms' debt ratios through time. The typical sample firm adjusts to its target debt ratio within a period of seventy weeks. Based on the positive target adjustment coefficient of 0.432 , the average firm in the sample adjusts to its target (period-specific) debt ratio within two years and four months so that the leverage half-life is 1.23 years. This result poses challenge for theories that insist on stability of debt ratios.

Finally, the study provides evidence in support of the market timing (or market conditions) model. This result is demonstrated by the inverse relation between leverage and market-to-book ratio and consistent with Baker [14].

\section{Conclusion}

The study has attempted an investigation of the impact of firm attributes on the capital structure of Nigerian firms. The motivation for the study is because this line of research is a largely under-explored area in Nigeria. The presence of market imperfections such as credit or liquidity squeeze, tax distortions, information problems, and agency problems would mean that the Nigerian market also provides an excellent laboratory for capital structure research and for subjecting the theories of capital structure to empirical tests. The study's key results are: the factors that exert positive influences on borrowing include prior borrowing or leverage, non-debt tax shields, assets' riskiness represented by R \&D and other intangible assets, age and rating; while the factors that exert negative influences are marginal tax rate, tangibility of assets in place, growth opportunities, size of the firm, volatility of operating earnings, profitability, liquidity and dividend-paying status.

Since financially constrained firms borrow more than their financially buoyant counterparts, leasing contracts can be utilized by the former in order to preserve borrowing capacity. This research has not examined separately the impact of leasing in capital structure choice because for most of the companies that had leasing contracts in this study, the arrangement was facilitated by banks and thus lumped together with financial liabilities. In addition, to minimize the pressure on firm's debt capacity, collateral-constrained firms should utilize leasing especially where the cash flows expected to be generated from the leased asset can repay the obligations.

The pecking order model outshines other common capital structure models in the Nigerian corporate environment. The results may thus be suggestive of information problems in the Nigerian financial markets. Thus, corporate and regulatory policies and instruments that enhance the information infrastructure of firms should be promoted. For instance, the adoption of international financial reporting standards (IFRS) in corporate reporting will enhance international comparison of indigenous firms with their foreign counterparts and boost attractiveness of Nigerian firms to foreign investors. To some degree, there are agency effects on capital structure choice as debt preference by small and less profitable firms implies that managers might be creditably issuing debt to pursue efficiency over glamour. It could also be the case that debt is the only option as most SMEs do not have access to public equity markets. The fact remains, however, that debt is a useful self-disciplinary tool for managers of small firms. Managers of large and profitable firms can exploit the tax advantages of debt along with its disciplinary role to boost corporate value. Target adjustment rationalizes capital structure instability despite positive adjustment costs. The speed of adjustment (SOA) is less than three years for the typical firm. Market timing behaviour is most visible during bullish period in the stock market. The evidence in support of trade-off model is weak.

The shift away from secured lending through pledging of 
firms' tangible assets may increase potential financial distress costs of firms. Though the practice of non-collateral lending presents enormous private and social benefits especially through the investment multiplier channel, the risks associated with the use of risky intangible assets such as $\mathrm{R}$ $\& \mathrm{D}$, patents, goodwill would include high asset substitution, high information asymmetry, non-transferability/ irreversibility and low second-hand value, and should not be ignored in credit contracts. For strategic sectors such as agriculture, the fiscal and monetary authorities can provide stimulus instruments to keep the flow of credit to critical sectors of the economy. The buoyancy of the fiscal space in the face of dwindling government revenue is a vital factor to gauge the ability of governments to provide such instruments. Paseda \& Obademi [84] explore macroeconomic effects on the capital structure of firms.

Another useful extension of the capital structure research in corporate finance is sovereign finance where the potential default costs from the use of foreign-currency denominated debt may be weighed against the inflation costs impact arising from domestic claims. Bolton \& Huang [20] provide an interesting and unifying perspective of monetary economics, international finance and fiscal policy along this path.

\section{Acknowledgements}

* This paper is an offshoot of the author's PhD thesis. An aspect of the paper was presented at seminars at the Faculty of Business Administration and Academic Programmes' Committee both of the University of Lagos. The author is grateful for the constructive comments and criticisms of the participants. Professors Olaseni Akintola-Bello, Rufus Olowe, Esther Adegbite, Wilfred Iyiegbuniwe, Sunday Owualah, Emeka Ezike, Ifuero O. Osamwonyi and Babatunde Oke get special thanks. The usual disclaimer applies.

As required, the author makes the following declarations:

1) Availability of data and materials: The data for this study are available on request. The sources of data have been disclosed in the "Methods" section of this study.

2) Competing interests: There are no competing interests in the conception, initiation and execution of this study.

3) Funding: No funding is provided for this study by any agency.

4) Authors' contributions: The corresponding author is the sole author of this study.

5) Acknowledgements: This work is an offshoot of the author's Ph.D. Thesis and the comments and criticisms of the supervisors and other members of the doctoral committee have been gratefully acknowledged.

\section{References}

[1] Adelegan, O. J. (2009) Investment, financial factors and cash flow from Nigerian panel data, Journal of African Development, $\quad 11 \quad$ (1): 77-108. https://ideas.repec.org/a/afe/journl/v11y2009i1p77-108.html
[2] Adelegan, O. J., \& Ariyo, A. (2008) Capital market imperfections and corporate investment behaviour: A switching regression approach using panel data for Nigerian manufacturing firms, Journal of Money, Investment and Banking, 2: 16-38. https://www.researchgate.net/publication/228340555_Capital_ market imperfections and corporate investment behavior $\bar{A}$ _switching_regression_approach_using_panel_data_for_Niger ian_manufacturing_firms

[3] Adenikinju, O. J. (2009) Capital structure and the risk of corporate failure: The case of Nigerian quoted companies, in Adenikinju, Busari \& Olofin (eds) Applied Econometrics \& Macroeconometric Modelling in Nigeria, Ibadan University Press. https://www.worldcat.org/title/applied-econometricsand-macroeconometric-modelling-in-nigeria/oclc/642923050

[4] Adesina, J. B., Nwidobie, B. M., \& Adesina, O. O. (2015) Capital structure and financial performance in Nigeria, International Journal of Business\& Social Research, 5 (2): 21-31. https://ideas.repec.org/a/mir/mirbus/v5y2015i2p2131.html

[5] Adesola, W. A. (2009) Testing static trade off theory against pecking order models of capital structure in Nigerian quoted firms, Global Journal of Social Sciences, 8 (1): 61-76. https://www.ajol.info/index.php/gjss/article/view/48883

[6] Agrawal, A., \& Matsa, D. (2013) Labour unemployment risk and corporate financing decisions, Journal of Financial $\begin{array}{llll}\text { Economics } & 108 & \text { (2): }\end{array}$ https://econpapers.repec.org/article/eeejfinec/v_3a108_3ay_3a 2013 3ai 3a2 3ap 3a449-470.htm

[7] Akintola-Bello, O. (2001) Forecasting appropriate P/E ratio, The Nigerian Stockbroker, 2 (4): 3-9.

[8] Akintola-Bello, O. (2004) The Nigerian Stock Market: Behaviour and Performance, Lagos: Arbitrage Consulting Group.

[9] Akintola-Bello, O., \& Adedipe, A. (1983) Estimating the cost of equity of Nigerian Firms, The Nigerian Journal of Economic and Social Studies, 20 (1): 99-106.

[10] Akinyomi, O. J. (2013) Effect of capital structure on firm performance: Evidence from Nigerian manufacturing industry, International Journal of Innovative Research and Studies, 2 (9): 468-480. https://www.researchgate.net/publication/259971167_

[11] Amah, P. N. (2014) Revisiting the effects of tax and bankruptcy costs on financing decisions among publicly listed firms in Nigeria, $5^{\text {th }}$ Annual International Conference on the Nigerian Financial System and Inclusive Growth and Development, 1: 183-193.

[12] Amah, P. N. \& Ezike, J. E. (2013) Investigating the relationship between corporate growth and debt policy: The Nigerian evidence, Journal of Money, Investment \& Banking, 27: $99-113$.

[13] Badoer, D. C., \& James, C. M. (2016) The determinants of long-term corporate debt issuances, Journal of Finance, 71 (1): 457-492. https://onlinelibrary.wiley.com/doi/abs/10.1111/jofi.12264

[14] Baker, M. (2009) Capital market-driven corporate finance, Annual Review of Financial Economics, 1: 181-205. https://doi.org/10.1146/annurev.financial.050808.114245 
[15] Barakat, M. H. \& Rao R. P. (2013) The role of taxes in capital structure: Evidence from taxed and non-taxed Arab economies, Working Paper, Oklahoma State University. https://mpra.ub.uni-muenchen.de/25472/

[16] Barclay, M. J., \& Smith, C. W. (2020) The capital structure puzzle: Another look at the evidence, Journal of Applied Corporate Finance, $32 \quad$ (1): 80-91 https://onlinelibrary.wiley.com/doi/abs/10.1111/jacf.12390

[17] Barrot, J-N. (2016) Trade credit and industry dynamics: Evidence from trucking firms, Journal of Finance, 71 (5): 1975-2016.

https://onlinelibrary.wiley.com/doi/abs/10.1111/jofi.12371

[18] Black, F., \& Scholes, M. (1973) The pricing of options and corporate liabilities, Journal of Political Economy, 81 (3): 637-659. https://www.jstor.org/stable/1831029

[19] Bolton, P. (2016) Debt and money: Financial constraints and sovereign finance, Journal of Finance 71 (4): 1483-1510. https://onlinelibrary.wiley.com/doi/abs/10.1111/jofi.12418

[20] Bolton, P. \& Huang, H. (2018) The capital structure of nations, Review of Finance, 22 (1): 45-82. https://doi.org/10.1093/rof/rfx042

[21] Brealey, R., Myers, S., \& Allen, F. (2020) Principles of Corporate Finance, $13^{\text {th }}$ Edition, McGrawHill Inc.

[22] Cerqueiro, G., Ongena, S. \& Roszbach, K. (2016) Collateralization, bank loan rates, and monitoring, Journal of Finance, 71 (3): 1295-1322. https://doi.org/10.1111/jofi.12214

[23] Chandrasekharan, C. V. (2012) Determinants of capital structure in the Nigerian listed firms, International Journal of Advanced Research in Management and Social Sciences, 1 (2): 108-133. https://www.google.com/url?sa=t\&rct=j\&q=\&esrc=s\&source $=$ web $\& \mathrm{~cd}=\& \mathrm{cad}=$ rja\&uact $=8 \& \mathrm{ved}=2 \mathrm{ahUKEwjM} 2 \mathrm{cSu} 3 \mathrm{cTr}$ Ah XWXRUIHbK-

[24] Chang, X. and S. Dasgupta (2009) Target behaviour and financing: How conclusive is the evidence? Journal of Finance, 64: 1767 -1796. https://doi.org/10.1111/j.15406261.2009.01479.x

[25] Chen, Y., Chen, C. R., \& Chu, C-K. (2014) The effect of executive stock options on corporate innovative activities, Financial Management, 43 (2): 271-290. DOI: $10.2307 / 43280182$

[26] Choi, J., \& Richardson, M. (2016) The volatility of a firm's assets and the leverage effect, Journal of Financial $\begin{array}{lrrr}\text { Economics, } & 121 & \text { (2): } & \text { 254-277. }\end{array}$ https://doi.org/10.1016/j.jfineco.2016.05.009

[27] Cohn, J. B., Titman, S. \& Twite, G. J. (2020) Capital structure and investor-level taxes: Evidence from a natural experiment in Europe, SSRN. https://dx.doi.org/10.2139/ssrn.2941957

[28] Copeland, T. E., Weston, J. F., \& Shastri, K. (2005) Financial Theory and Corporate Policy, $4^{\text {th }}$ Edition, Boston, MA: Pearson Addison-Wesley. https://afajof.org/wpcontent/uploads/files/historicaltexts/Financial_Theory_and_Corpora.pdf

[29] Cronqvist, H., Makhija, A. K.\&Yonker, S. E. (2012) Behavioural consistency in corporate finance: CEO personal and corporate leverage, Journal of Financial Economics 103: 20-40. https://doi.org/10.1016/j.jfineco.2011.08.005
[30] DeAngelo, H., \& Masulis, R. (1980) Optimal capital structure under corporate and personal taxation, Journal of Financial Economics, 8 (1): 5-29. https://doi.org/10.1016/0304405X(80)90019-7

[31] DeAngelo, H. \& Roll, R. (2015) How stable are corporate capital structures? Journal of Finance, 70 (1): 373-418. https://doi.org/10.1111/jofi.12163

[32] De Jong, A., Nguyen, T. T., \& Kabir, R. (2008) Capital structure around the World: The roles of firm- and countryspecific determinants, Journal of Banking \& Finance, 32 (9): 1954-1969. https://doi.org/10.1016/j.jbankfin.2007.12.034

[33] Demirguc-Kunt, A., Peria, MSM, Tressel, T. (2020) The global financial crisis and the capital structure of firms: Was the impact more severe among SMEs and non-listed firms? Journal of Corporate Finance, 60 (1): 1-32. https://doi.org/10.1016/j.jcorpfin.2019.101514

[34] Ezeoha, A. E., \& Okafor, F. O. (2010) Local corporate ownership and capital structure decisions in Nigeria: A developing country perspective, Corporate Governance, 10 (3): 249-260. https://doi.org/10.1108/14720701011051893

[35] Fama, E., \&French, K. (2002) Testing tradeoff and pecking order predictions about dividends and debt, Review of Financial Studies, 15: 1-33. DOI: 10.2307/2696797.

[36] Fama, E. F. \&French, K. R. (2005) Financing decisions: Who issues stock? Journal of Financial Economics, 76: 549 - 582. https://doi.org/10.1016/j.jfineco.2004.10.003

[37] Fama, E.F. \&French, K. R. (2012) Capital structure choices, Critical Finance Review, 1: 59-101. https://econpapers.repec.org/article/nowjnlcfr/104.00000002.h tm

[38] Fama, E. F. \&Miller, M. H. (1972) The Theory of Finance, Holt Reinhart and Winston.

[39] Fan, J., Titman, S. \& Twite, G. (2012) An international comparison of capital structure and debt maturity choices, Journal of Financial and Quantitative Analysis, 47 (1): 23-56. https://doi.org/10.1017/S0022109011000597

[40] Ferres, D., Ormazabal, G., Povel, P. \& Sertsios, G. (2020) Capital structure under collusion, Journal of Financial Intermediation, Available online 08 February 2020. https://doi.org/10.1016/j.jfi.2020.100854

[41] Frank, M. Z., \&Goyal, V. K. (2003) Testing the pecking order theory of capital structure, Journal of Financial Economics, 67: 217-248. https://doi.org/10.1016/S0304-405X(02)00252-0

[42] Frank, M. Z., \& Goyal, V. K. (2009) Financial Management, 38 (1): 1- 37. Capital structure decisions: Which factors are reliably important? https://doi.org/10.1111/j.1755-053X.2009.01026.x

[43] Frank, M. Z., \& Shen, T. (2014) Common factors in corporate capital structures, Working Paper, University of Minnesota. DOI: $10.2139 / \mathrm{ssrn} .2288767$.

[44] Glover, B. (2016) The expected cost of default, Journal of Financial Economics, 119: 284-299. https://doi.org/10.1016/j.jfineco.2015.09.007

[45] Graham, J. R. (2000) How big are the tax benefits of debts? Journal of Finance, 55 (5): 1901-1941. https://doi.org/10.1111/0022-1082.00277 
[46] Graham, J. R. \&Tucker, A. L. (2006) Tax shelters and corporate debt policy, Journal of Financial Economics, 81: 563-594. https://doi.org/10.1016/j.jfineco.2005.09.002

[47] Graham, J. R., Leary, M. T. \&Roberts, M. (2014a) A century of capital structure: The leveraging of corporate America, NBER Working Paper 19910, February 2014 http://www.nber.org/papers/w19910.

[48] Graham, J. R., Leary, M. T.,\& Roberts, M. (2014b) How does government borrowing affect corporate financing and investment? NBER Working Paper, April 16, 2014. DOI: $10.3386 / \mathrm{w} 20581$

[49] Grossman, S. J., \& Hart, O. (1982) Corporate financial structure and managerial incentives, In John McCall ed., The Economics of Information and Uncertainty (University of Chicago Press), 1: 107-140. https://ssrn.com/abstract=578641

[50] Gwatidzo, T. (2008) Capital Structure of African Firms: Case Study of Kenya, Ghana, Nigeria and South Africa, Ph.D. Thesis University of South Africa, $09^{\text {th }}$ October 2008.

[51] Harris, M. \&Raviv, A. (1991) The theory of capital structure, Journal of Finance, 46 (1): 297-355. https://doi.org/10.1111/j.1540-6261.1991.tb03753.x

[52] Hart, O. \& Moore, J. (1995) Debt and seniority: An analysis of the role of hard claims in constraining management, American Economic Review, 85 (3): 567-585. DOI: 10.2307/2118188.

[53] Huang, R., \&Ritter, J. (2009) Testing theories of capital structure and estimating the speed of adjustment, Journal of Financial and Quantitative Analysis, 44: 237-271. DOI: $10.2307 / 40505924$

[54] Iyiegbuniwe, W. C. (2007) The Essence of Finance: Maximizing Life-Time Happiness, Inaugural Lecture Delivered at the University of Lagos Main Auditorium (31 ${ }^{\text {st }}$ January 2007).

[55] Jensen, M. C. (1986) Agency costs of free cash flow, corporate finance and takeovers, American Economic Review, 76 (2): 323-329. DOI: $10.2307 / 1818789$.

[56] Jensen, M. C. \& Meckling, W. (1976) Theory of the firm: Managerial behaviour, agency costs and ownership structure, Journal of Financial Economics, 3 (4): 305-360. https://doi.org/10.1016/0304-405X(76)90026-X

[57] Kim, H. (2020) How does labour market size affect firm capital structure? Evidence from large plant openings, Journal of Financial Economics, Available online 4 May 2020, https://doi.org/10.1016/j.fineco.2020.04.012

[58] Leary, M. T. \&Roberts, M. R. (2005) Do firms rebalance their capital structures? Journal of Finance, 60: 2575 - 2619. https://doi.org/10.1111/j.1540-6261.2005.00811.x

[59] Leary, M. T. \&Roberts, M. R. (2014) Do peer firms affect corporate financial policy? Journal of Finance, 69 (1): 139 178. https://doi.org/10.1111/jofi.12094

[60] Lemmon, M., Roberts, M. \&Zender, J. (2008) Back to the beginning: persistence and the cross section of corporate capital structure, Journal of Finance, 63: 1575-1608. https://doi.org/10.1111/j.1540-6261.2008.01369.x

[61] Lewellen, K. (2006) Financing decisions when managers are risk averse, Journal of Financial Economics, 82: 551-589. https://doi.org/10.1016/j.jfineco.2005.06.009
[62] Lilienfeld-Toal, U. V. \& S. Ruenzi (2014) CEO ownership, stock market performance and managerial discretion, Journal of Finance, 69 (3): 1013-1050. DOI: 10.2307/43611178.

[63] Machokoto, M., Areneke, G. \& Ibrahim, B. M. (2020) Rising corporate debt and value relevance of supply-side factors in South Africa, Journal of Business Research, 109 (1): 26-37 https://doi.org/10.1016/j.jbusres.2019.11.039

[64] Maes, E., Dewaelheyns, N., Fuss, C., \& van Hulle, C. (2019) The impact of exporting on financial debt choices of SMEs, Journal of Business Research, 102: 56-73 https://doi.org/10.1016/j.jbusres.2019.05.008

[65] Merton, R. C. (1973) Rational theory of option pricing, Bell Journal of Economics and Management Science, 4 (1): 141183. DOI: $10.2307 / 3003143$.

[66] Miller, M. H. (1977) Debt and taxes, Journal of Finance, 32: 261-276. https://doi.org/10.1111/j.1540-6261.1977.tb03267.x

[67] Miller, M. H. (1995) Do the M\&M propositions apply to banks? Journal of Banking and Finance, 19: 483-489. https://doi.org/10.1016/0378-4266(94)00134-O

[68] Modigliani, F. \& Miller, M. H. (1958) The cost of capital, corporation finance and the theory of investment, American Economic Review, 48: 261-296. DOI: 10.2307/1809766.

[69] Modigliani, F. \&Miller, M. H. (1963) Corporate income taxes and the cost of capital: A correction, American Economic Review, 53: 433-443. https://www.jstor.org/stable/1809167?seq=1

[70] Myers, S. C. (1977) The determinants of corporate borrowing, Journal of Financial Economics, 5: 147-175. https://www.sciencedirect.com/science/article/abs/pii/03044 05X77900150

[71] Myers, S. C. (1984) The capital structure puzzle, Journal of Finance, $\quad 39: \quad 575 \quad-592$ https://onlinelibrary.wiley.com/doi/full/10.1111/j.15406261.1984.tb03646.x

[72] Myers, S. C (2001) Capital Structure, Journal of Economic Perspectives, $\quad 15 \quad$ (2): https://www.aeaweb.org/articles?id=10.1257/jep.15.2.81

[73] Myers, S. C. \& Majluf, N. S. (1984) Corporate financing and investment decisions when firms have information the investors do not have, Journal of Financial Economics, 13: 187 - 221. https://www.sciencedirect.com/science/article/abs/pii/0304405X 84900230

[74] Olokoyo, F. O. (2012) Capital Structure and Corporate Performance of Nigerian Quoted Firms, Ph.D. Thesis, Department of Banking \& Finance, Covenant University.

[75] Olowe, R. (2009) Stock Return Volatility and the Global Financial Crisis in an Emerging Market: The Nigerian Case, International Review of Business Research Papers, 5 (4): 426447. https://www.researchgate.net/publication/228676340

[76] Olowe, R. A. (2011) Real Stock Returns, Volatility and Real Economic Activity: Evidence from Nigeria, Journal of Management Review, 1 (1): 11-42.

[77] Owualah, S. I. (2014) Finance and Entrepreneurship: Rod and Staff through the Valley of Unemployment, (Inaugural Lecture October 22, 2014), University of Lagos Ltd. https://ir.unilag.edu.ng/handle/123456789/769 
[78] Oyejide, T. A. (1987) The impact of equity capital, retained earnings and debt on corporate profits in Nigeria, The Nigerian Journal of Economic and Social Studies, 29 (1): 3545. https://www.africabib.org/rec.php?RID=119535947

[79] Parsons, C., \&Titman S. (2008) Empirical capital structure: A review, Foundations and Trends in Finance 3: 1- 93. DOI: 10.1561/0500000018.

[80] Paseda, O. A. (2016) The determinants of capital structure of Nigerian quoted firms, Ph.D. Thesis, Department of Finance, University of Lagos, Nigeria. https://dx.doi.org/10.2139/ssrn.2890900

[81] Paseda, O. A. (2020a) The impact of taxes on the borrowing behaviour of Nigerian quoted firms, Pakistan Journal of Social Sciences, 17 (1): 59-76.

[82] Paseda, O. A. (2020b) Information in the tax benefit curves of selected Nigerian quoted firms, IOSR Journal of Economics and Finance, 11 (4S2): 54-71.

[83] Paseda, O. A. \& Adedeji, B. S. (2020) The mystery of zeroleverage firms: Evidence from Nigerian quoted firms, GATR Accounting and Finance Review, 5 (2): 28-55.

[84] Paseda, O. A. \& Obademi, O. (2020) Macroeconomic variables and their effects on the capital structure of quoted Nigerian firms, Finance and Banking Review, 14 (1): 31-51.

[85] Rajan, R. \& Zingales, L. (1995) What do we know about capital structure? Some evidence from international data, Journal of Finance, 50: 1421-1460. DOI: 10.2307/2329322.
[86] Soyibo, A. (1996) Determinants of choice of investment finance by Nigerian firms, African Journal of Economic Policy, 3 (1): 35-45.

[87] Soyode, A. (1975) Dividend policy in an era of indigenization: Comment, The Nigerian Journal of Economic and Social Studies, 17 (2): 149-154.

[88] Soyode, A. (1978) Financing industrial growth in Nigeria: A study of the place of debt and retained earnings, Journal of Management, Ghana, 10 (1): 26-31.

[89] Strebulaev, I. (2007) Do tests of capital structure theory mean what they say? Journal of Finance, 62 (4): 1747-1787. https://onlinelibrary.wiley.com/doi/10.1111/j.15406261.2007.01256.x

[90] Strebulaev, I. \&Yang, B. (2013) The mystery of zero-leverage firms, Journal of Financial Economics, 109: 1-23. https://doi.org/10.1016/j.jfineco.2013.02.001

[91] Titman, S. \& Wessels, R. (1988) The determinants of capital structure, Journal of Finance, 43: 1-19. https://doi.org/10.1111/j.1540-6261.1988.tb02585.x

[92] Welch, I. (2011) Two common problems in capital structure research, International Review of Finance, 11 (1): 1-17. DOI: j.1468-2443.2010.01125.x.

[93] Welch, I. (2015) Corporate finance: An introduction, $2^{\text {nd }}$ Edition, Pearson Education.

[94] Zingales, L. (2015) Does finance benefit society, Journal of Finance, 70 (4): 1327 - 1363. https://doi.org/10.1111/jofi.12295 